\title{
DOES HEADQUARTER STRUCTURE FOLLOW CORPORATE STRATEGY? AN EMPIRICAL STUDY OF ANTECEDENTS AND CONSEQUENCES OF CHANGES IN THE SIZE OF CORPORATE HEADQUARTERS
}

\author{
Sven KUNISCH \\ Institute of Management, University of St.Gallen Dufourstrasse 40a, \\ 9000 St. Gallen, Switzerland \\ E-mail: Sven.Kunisch@unisg.ch
}

Received 13 July 2016; accepted 11 February 2017

\begin{abstract}
Despite the importance that scholars and practicing managers attribute to the organizational design of the corporate headquarters (CHQ), research on changes in CHQ size is lacking. In an attempt to empirically explore the antecedents and potential consequences of such changes, I draw on the contingency and organizational-adaptation perspectives to develop a set of hypotheses for the relationships between corporate-level strategic change (CSC) - defined as changes in the firm's business portfolio -, changes in the size of the CHQ and firm performance. To test the hypotheses, I analyse data from a comprehensive survey of large public firms in Europe and the US, and data from public sources pertaining to the surveyed firms. While the empirical results lend support to the hypothesized role of CSC, they also reveal differences between related CSC and unrelated CSC. However, I find no support for the expected performance implications. The study contributes to research on the CHQ, corporate-level strategic change, and the relationship between strategy and structure in the contemporary corporation. The findings also inform corporate managers and those involved in advising firms, such as strategy consultants.
\end{abstract}

Keywords: corporate headquarters, corporate headquarters change, corporate strategy, strategic change, organizational contingency theory, organizational adaptation.

JEL Classification: D23, L21, L22, L25, M10.

\section{Introduction}

The corporate headquarters (CHQ) is crucial for the success of today's corporations (Chandler 1991; Menz et al. 2015). Since Chandler (1962) turned the spotlight on the CHQ, a vast body of knowledge has accumulated on this entity's roles, functions, size, structure, location, and its internal and external relationships (for a comprehensive review, see Menz et al. 2015). Although most of this research is static, scholars have recently become more interested in studying changes at the CHQ (Kunisch et al. 2015). This research has shed light on several dynamic phenomena, such as CHQ relocations 
(Birkinshaw et al. 2006; Laamanen et al. 2012; Baaij et al. 2015) and the lifecycle of CHQ units (Kunisch et al. 2014). Yet, changes in the structure of the CHQ have not received much scholarly attention.

The lack of research in this area stands in sharp contrast to the importance scholars attach to the size and structure of the CHQ. Prior studies stress that the CHQ's size and structure are fundamental concerns for large firms (Porter 1987; Young 1993; Buehner 2000; Stalk Jr. 2005; Collis et al. 2007, 2012). Although these studies provide important insights into the organizational design of the $\mathrm{CHQ}$, they offer little information about when firms change the size and structure of their $\mathrm{CHQ}$, and whether or not they benefit from such endeavours.

The lack of knowledge is also problematic because academics are unable to provide advice to managers, who view changes at the CHQ as highly important (Young et al. 2000; Kontes 2004; Economist 2008, 2014). For example, according to a recent survey of the largest firms in North America and Europe two thirds of firms engaged in major changes at their CHQ over a four-year period and $85 \%$ did so over a ten-year period (Kunisch et al. 2012). Incidentally, the business press also frequently calls for CHQ staff downsizing (Economist 2008, 2014). Yet, we lack empirical evidence demonstrating that reductions in CHQ staff are beneficial. In fact, the limited research on the CHQ size-performance relationship suggests that firms with larger CHQ often outperform those with smaller CHQ (Goold, Young 2005; Collis et al. 2007). Hence, theoretically informed research on the antecedents and consequences of changes at the CHQ as well as testing in the field are urgently needed to provide managers with scholarly advice, especially because such changes are often major undertakings that consume significant organizational resources (Kunisch et al. 2015).

Because the CHQ is responsible for managing the firm's portfolio of businesses and for creating a corporate advantage (Chandler 1991; Campbell et al. 1995; Collis, Montgomery 1998), the relationships between changes in the business portfolio and changes in the design of the CHQ are particularly interesting. For the purpose of this study, I follow others (Ginsberg 1988; Goodstein, Boeker 1991; Wiersema, Bantel 1992) in conceptualizing changes in the business portfolio as corporate strategic change (CSC) ${ }^{1}$. On this basis, this study attempts to answer two interrelated questions: (1) What are the relationships between CSC and changes in CHQ size? (2) What are the performance implications of changes in CHQ size?

To tackle the research questions, I draw on the contingency and organizational-adaptation perspectives, and argue that changes in the size of the CHQ are contingent upon $\mathrm{CSC}$, and that firms benefit from adapting their CHQ to changes in the business portfolios. Specifically, I argue that changes in the related elements of the business portfolio - related CSC - rather than changes in its unrelated elements - unrelated CSC - are

\footnotetext{
${ }^{1}$ I thank one of the anonymous reviewers for pointing out that change at the CHQ can also be a kind of corporate strategic change (see Kunisch et al. 2015). Moreover, although the delineation between "strategic change" and other "organizational change" is controversial (Mintzberg, Westely 1992), I treat changes in CHQ size as organizational change rather than strategic change.
} 
associated with changes in CHQ size and with performance benefits, as related CSC is likely to affect the potential for economic benefits and corporate-level synergies. I test the hypotheses using data from a comprehensive CHQ survey, and data from public sources pertaining to a sample of large, public firms in the US and Europe.

\section{Background}

The contemporary corporation is characterized by a set of product and/or geographical business activities and a distinct organizational unit at the top of the corporate hierarchy, which is often referred to as the CHQ (Chandler 1962, 1991, 1992; Menz et al. 2015). Competition among these firms occurs not only on the business level but also on the corporate level (Porter 1987; Campbell et al. 1995; Collis, Montgomery 1998).

\subsection{Corporate strategy and the CHQ}

Although a comprehensive review of the CHQ literature is beyond the scope of this study, two lines of research are noteworthy. The first centres on the roles and activities of the CHQ - its general raison d'être. According to Chandler (1962, 1991), the CHQ plays at least two distinct roles: an administrative role in which it monitors and controls the activities of the business units (Williamson 1975), and an entrepreneurial role in which it serves as an additional source of value. While the former is mostly concerned with "avoiding the negative", the latter is more concerned with "creating the positive" (Foss 1997). The entrepreneurial role is more discretionary, and the extent to which it is executed can vary substantively among firms (Goold et al. 2001). Chandler (1991) recognizes a third role in a footnote - handling external relations with shareholders (Birkinshaw et al. 2006), government agencies, or non-government organizations.

The second line of research centres on the CHQ design. This research is closely related to the roles of the CHQ that are viewed as a key determinant of the entity's organizational design. For example, Goold and Campbell (1987) described three different corporate management styles - strategic planning, strategic control and financial control - each of which influence CHQ size and structure. In a similar vein, Porter (1987) described organizational prerequisites at the CHQ for each of his four concepts of corporate strategy. A few studies empirically tested determinants of CHQ structure and size (Collis et al. 2007, 2012). Although these works provide initial insights into the relationships between a firms' business portfolio and the CHQ's design, the relationships between changes in the firm's business portfolio and structural change at the CHQ (which manages the business portfolio) are still unexplored.

\subsection{Theoretical perspectives}

While the CHQ plays a role in many theories of the firm (Kleinbaum, Stuart 2014; Menz et al. 2015), especially contingency theory has helped explain various CHQ phenomena (Young et al. 2000; Collis et al. 2007, 2012). Contingency theory, which originated with the works of Burns and Stalker (1961) and Lawrence and Lorsch (1967), postulates that there is no "one best way". Instead, the suitability of managerial decisions is contingent upon the firms' internal and external environments (Donaldson 1995, 2001). 
Relevant situational factors include technical and market changes (Burns, Stalker 1961), the organization's size (Blau 1970), and the firm's strategy (Chandler 1962; Miles, Snow 1978). Organizational contingency theory has been used in studies of various organizational-design phenomena, such as the adoption of the M-form, structural differentiation, formalization and decentralization (cf. Donaldson 2001) ${ }^{2}$. It has also been used in studies of topics closely related to the CHQ, such as structural alignment in the top management team (TMT) (Hambrick, Cannella 2004; Marcel 2009; Menz, Scheef 2014) and in studies of organizational change (Battilana, Casciaro 2012).

Organizational adaptation theory, which is closely related to contingency theory, explicitly emphasizes organizational change, and posits that firms adapt their structures to cope with changes in their internal and external environments (Mueller, Kunisch 2017). For example, low firm performance fosters CSC (Kimberly, Quinn 1984). This lens has been applied in studies pertaining to various elements of the CHQ, such as leadership structures at the corporate level (Zhang 2006).

The common premise of these perspectives is that decision makers rationally strive to align their firms with the situation in the internal and external environments, and that the firm's performance depends on the extent to which fit has been achieved (Lawrence, Lorsch 1967; Donaldson 2001). Hence, these two lenses deviate from other prominent views on organizational choice, such as institutional theory's claim that decision makers imitate others (DiMaggio, Powell 1983), the upper echelons' logic that managers act on the basis of their values and prior experiences (Hambrick, Mason 1984), and agency theory's premise that managers strive to optimize their own benefits rather than those of shareholders (Jensen, Meckling 1976) ${ }^{3}$. Moreover, these two lenses differ from other well-known theories of change that allow for much less managerial choice, such as population ecology's (Hannan, Freeman 1977, 1989) proposition that "structural inertia" inhibits organizational change (Hannan, Freeman 1984).

To maintain a coherent theoretical framework, in this study I focus on the premises of the contingency and adaptation lenses. In what follows, I propose that structural change at the CHQ is contingent upon CSC. In addition, I propose that depending on the extent to which CSC occurs structural change at the $\mathrm{CHQ}$ has positive performance effects, as such change is needed to regain internal fit between the two corporate-strategy aspects.

\section{Hypotheses}

\subsection{Antecedents: corporate strategic change}

Prior research suggests that the business portfolio serves as an important determinant of CHQ size (Porter 1987; Collis et al. 2007). Different business portfolios need to be managed in different ways simply because the potential for economic benefit varies (Rumelt

\footnotetext{
${ }^{2}$ Please note that this theory has also been used in other areas of management. See, for example, Chiarini and Vagnoni (2015) and Chiarini (2016).

${ }^{3}$ In this regard, I follow Hambrick and Cannella (2004), who make a similar argument in their study of the existence of COOs in which they rely on the contingency view.
} 
1982; Palepu 1985; Hill, Hoskisson 1987). The identification and, ultimately, the exploitation of synergies among business units require effort from the CHQ. For example, the creation of synergies requires an ability to transfer skills or share activities among separate business units, which needs to be coordinated and organized (Porter 1987).

Given this logic, changes in the business portfolio alter the potential for certain economic benefits. This, in turn, should foster a need to adapt organizational arrangements - especially the CHQ's design - to realize those economic benefits. In fact, the limited available empirical evidence suggests that changes in the corporate portfolio are related to changes in CHQ functions and roles. For example, Cibin and Grant (1996) link changes in the corporate strategy (i.e. a narrowing of scope) to various changes at the CHQ, including decentralization, less formality, less specialization, a quest for non-hierarchical systems of coordination and control, and a redefinition of the roles of TMT members and CHQ staff.

Based on this line of argumentation, I expect changes in the business portfolio to foster change at the CHQ:

H1: CSC is positively related to the likelihood of change in CHQ size.

A key premise of diversification research is that substantial differences can be found in similarly diversified firms, especially in the related and unrelated elements of the business portfolio (Palepu 1985). As change can occur in the related and/or unrelated elements of the business portfolio, CSC can also differ widely. My second hypothesis is therefore more specific with respect to CSC, i.e. the potential changes in firms' portfolio of businesses.

Related diversification and unrelated diversification are managed in different ways because distinct economic benefits are associated with each diversification strategy (Hill, Hoskisson 1987; Porter 1987; Hoskisson, Hitt 1988; Jones, Hill 1988; Hill et al. 1992). While related diversification relies on synergistic economies (i.e. economies of scope, economies of integration and internal capital markets), unrelated diversification mainly benefits from financial economies (i.e. internal capital markets) and efficient internal governance mechanisms. Consequently, the two diversification strategies require certain organizational arrangements (e.g. controls) to ensure the realization of their respective economic benefits. Even though scholars often do not explicitly refer to the CHQ, these organizational arrangements relate to the CHQ.

Extant research on the CHQ suggests that relatedness of firms' portfolio of businesses is positively associated with CHQ size (Collis et al. 2007). Firms pursuing related diversification typically have larger CHQs, while firms pursuing unrelated diversification usually require fewer corporate-level staff and, thus, have smaller CHQs (Dundas, Richardson 1982). In this regard, Collis and Montgomery (1998: 73) state: "the more general the resources and the less the need for sharing, the smaller the corporate office should be". Thus, CHQ sizes should differ greatly between firms engaging in related diversification and those engaging in unrelated diversification.

On this basis, I suggest that changes in the related and unrelated elements of the business portfolio are likely to affect the CHQ in different ways. Related CSC means moving from 
a lower level of related diversification to a higher level or vice versa. Synergies associated with the related elements in the business portfolio play a less important role given lower levels of related diversification, but they are more important given higher levels of related diversification. In both cases, synergies play more important roles at certain points in time. When the potential for creating synergies is high, additional functions are usually required at the corporate level to realize economic benefits. Similarly, when the potential for creating synergies is low, fewer staff members and functions are required. In other words, as certain organizational arrangements are required at the CHQ to realize synergies, related CSC can be expected to lead to structural changes at the CHQ.

Conversely, unrelated CSC means that firms switch from a lower to a higher level of unrelated diversification or vice versa. In either case, the change only affects the economic benefits associated with the unrelated diversification (e.g. financial economies [internal capital markets] and the efficiency of internal-governance mechanisms), which should have a limited influence on CHQ size. Hence, structural change at the CHQ should be less likely.

In sum, I expect changes in the related elements in the business portfolio - related CSC - to be more likely to foster change in CHQ size than changes in the unrelated elements - unrelated CSC. To reflect these potential differences, I state two hypotheses:

H2: a) Related CSC and b) unrelated CSC are positively related to the likelihood of change in CHQ size.

\subsection{Consequences: firm performance}

The lenses applied in this study lead me to suggest contingency effects. Although there is no systematic evidence that structural changes at the CHQ have performance implications, an essential tenet of organizational contingency theory is that organizations need to be internally aligned and that internal fit leads to superior performance (Lorsch, Allen 1973; Donaldson 1987, 2001). Common themes in (static) CHQ research are that the design of the CHQ entity is a key factor for performance, and that the fit between the portfolio strategy and the organizational design (structure) on the firm and CHQ levels is crucial for superior performance (Menz et al. 2015).

Changes in the business portfolio alter the fit between the business portfolio and the CHQ's organizational arrangements suited to effectively manage that portfolio. This suggests that CSC in conjunction with a change in CHQ size results in superior performance - the CHQ's design must be adjusted to re-establish internal fit between the two corporate-strategy aspects. The achievement of fit between the business portfolio and the organizational arrangements at the CHQ allows the benefits described above to outweigh the costs. As fit is associated with superior performance (Donaldson 1987), firms that succeed in establishing fit between the two aspects of corporate strategy should enjoy superior performance.

Based on this logic and bearing in mind the arguments pertaining to the antecedents of change in CHQ size, CSC accompanied by structural change at the CHQ should lead to superior performance. I therefore submit the following general hypothesis:

H3: Firms benefit from changes in CHQ size to the extent that CSC occurs. 
In addition, building on the differences between changes in the business portfolio discussed above, I submit two specific hypotheses:

H4: Firms benefit from changes in CHQ size to the extent that a) related CSC occurs, and b) unrelated CSC occurs.

\section{Methodology}

\subsection{Sample and data collection}

To test the hypotheses, I compiled a data set from two sources. First, in line with prior CHQ research (Buehner 2000; Young et al. 2000; Collis et al. 2007, 2012), I used survey data to capture information about structural changes at the CHQ in four countries: Germany (DE), the Netherlands (NL), the United Kingdom (UK) and the United States (US). The surveys were conducted by an international research consortium (for detailed information, please see Collis et al. (2007: 384-385)). While the original surveys covered six countries, I could only gain access to four of them, which cover the North American and Continental European corporate governance systems. This data set covered 170 publicly listed firms.

Second, for the firms included in the survey sample, I collected publically available data on CSC, firm performance and environmental characteristics. Data on the firms' business activities and financial data were obtained from the Thomson Reuters OneBanker database. As the analysis spans several years, several firms disappeared from the data set at some point and/or had missing data. These factors reduced the final samples to 116 and 104 firms, respectively.

\subsection{Variables}

In order to explore causal relationships, I relied on time lags between the dependent variables and the independent variables. Data capturing the anticipated changes at the CHQ lagged the data capturing CSC, while the performance data lagged the data capturing previous changes at the CHQ and CSC.

\subsubsection{Changes in $\mathrm{CHQ}$ size}

Two survey questions captured changes in $C H Q$ size. One question asked about prior changes ("How has the number of CHQ staff changed over the previous five years?"), while the other asked about likely future changes ("What changes do you anticipate in the number of CHQ staff over the next five years?"). The informants were asked to indicate whether the number of CHQ staff was (would be) lower, the same $( \pm 10 \%)$ or higher (see Young et al. 2000). Based on the data from these two questions, I created two dummy variables to capture changes in CHQ size - one to capture anticipated changes and another to capture previous changes. Each of the two binary variables was coded 1 for change and 0 for no change.

\subsubsection{Corporate-level strategic change (CSC)}

Corporate strategy concerns the mix and weight of businesses within the corporate portfolio (Ansoff 1965; Rumelt 1974; Porter 1987). In line with this definition and the study's purpose of linking the two concerns of corporate strategy, I measured CSC as the 
change in the firm's diversification strategy. As in previous studies (Wiersema, Bantel 1992), I based the measure of diversification strategy on the entropy measure of total diversification (DT) (Jacquemin, Berry 1979) which captures both the diversity of the business portfolio and the related versus unrelated elements of diversity (Palepu 1985). The DT index has been widely used in prior corporate strategy studies (Hill et al. 1992; Bigley, Wiersema 2002). While related diversification (DR) captures the "distribution of the output among related products within the industry group" (Palepu 1985: 244), unrelated diversification (DU) measures "the extent to which a firm's output is distributed in products across unrelated industry groups" (Palepu 1985: 244). I used the DR and DU indexes to capture the related and unrelated diversification.

On the basis of this logic, CSC was measured as the absolute difference between the entropy measures of diversification in two years: $t$ and $t-3$ (Wiersema, Bantel 1992; Bigley, Wiersema 2002; Kunisch et al. 2017). More specifically, I used the $1998(t)$ and $1995(t-3)$ entropy measures of diversification to calculate CSC. To better understand the relationships between CSC and changes in the size of the CHQ, I calculated three measures for CSC, one for each of the three entropy measures of diversification: total CSC (CSCT), related CSC (CSCR) and unrelated CSC (CSCU).

\subsubsection{Firm performance}

I measured firm performance as the efficiency of resource use within the firm as a whole, as my arguments largely centre on the efficiency effects of establishing fit between corporate strategy and structure. I used the return on assets (RoA) to measure profitability. This performance indicator is used in other studies investigating the fit between strategy and structure (Hill et al. 1992). Similar to previous studies (Bigley, Wiersema 2002), I used a three-year average RoA to even out annual fluctuations in the financial data.

\subsubsection{Controls}

To account for potentially confounding effects and alternative explanations, I considered control variables at the CHQ, firm and environmental levels.

Relative $\mathrm{CHQ}$ size. I calculated $\mathrm{CHQ}$ size as the natural logarithm of the number of CHQ staff per 1,000 employees in the organization as a whole (Collis et al. 2007, 2012).

$\mathrm{CHQ}$ and firm performance. I controlled for prior performance. I followed the approach taken by Collis et al. (2007) in using two types of performance measures, each of which has unique advantages and disadvantages. I controlled for $C H Q$ performance using two self-reported measures: (1) the ability to support corporate strategy and (2) the cost effectiveness of the CHQ. Although these measures are rather subjective, they directly evaluate CHQ performance (Collis et al. 2007). In addition, I used financial performance measures, which can be influenced by many factors other than CHQ performance but are rather objective. In line with the logic for firm performance explained above, I used a three-year average $R o A$.

Degree of diversification. I used the three entropy measures to account for the firm's degree of total, related and unrelated diversification (see details above).

Firm size. I followed previous studies (Boeker 1997; Carpenter 2000) in controlling for 
firm size, as it has been argued that firm size may be related to change (Mintzberg 1978; Hannan, Freeman 1989; Haveman 1993). I used the firm's market capitalization to measure firm size. As in prior studies (Kelly, Amburgey 1991; Carpenter 2000; Collis et al. 2007), I calculated the natural logarithm, as the distribution of the values was skewed.

Industry. I used the Thomson Reuters OneBanker general industry classification to create six industry dummies (01 = "Industrial", 02 = "Utility", 03 = "Transportation", $04=$ "Banks/Savings and Loans", 05 = "Insurance" and $06=$ "Other Financial"). I created an additional industry dummy to distinguish between industrial and non-industrial firms. Country. I created four dummies for the countries in the sample (DE, NL, US, UK), and used three of them in the analyses, with NL as the omitted country. I also created a region dummy to distinguish between US and non-US firms.

\subsection{Analytical procedures, validity and reliability}

To test the hypothesized antecedents and consequences, I applied two types of regression analyses (Sanders, Carpenter 1998) to account for the nature of the respective dependent variables. Given the binary nature of change in $\mathrm{CHQ}$ size, I applied binominal logit regression analyses (Menard 1995; Hoetker 2007; Wiersema, Bowen 2009) to estimate the likelihood of change in $C H Q$ size. I relied on OLS regressions to analyse the hypothesized performance consequences of changes in $\mathrm{CHQ}$ size (Baron, Kenny 1986; Aiken, West 1991).

To capture the moderation effects with regard to CSC, related CSC and unrelated CSC, I created three sets of dummy variables. Each set contained two binary variables. The first variable was coded 1 if $C S C$ ( $C S C R$ and $C S C U$, respectively) was high and the CHQ's size changed, and 0 otherwise. The second variable was coded 1 if CSC (CSCR and $C S C U$, respectively) was high and the CHQ's size remained unchanged. A high level of CSC (CSCR and CSCU, respectively) was defined as the mean value plus 0.5 of the standard deviation.

I addressed validity and reliability issues in several ways. First, I used two different sources of data (survey or secondary data) for the dependent and independent variables to address a potential single-source bias (Cardinal 2001). Second, all of the measures used in this study have been validated in prior studies. Third, I conducted several robustness checks.

\section{Results}

A first key insight is that there is considerable variance among the firms with respect to changes in CHQ size. As shown in Tables 1 and 2, while approximately 44\% of the firms did not anticipate changes in the size of their CHQs in the next five years, $56 \%$ did expect such changes. The numbers for past changes are slightly different - approximately one third had not changed the size of their CHQs in the previous five years, while two thirds had changed their CHQ' size.

In the following, I describe the analyses of factors that influence the likelihood of such changes and their potential consequences. 
Table 1. Magnitude and directionality of change in CHQ size

\begin{tabular}{|c|c|c|c|c|}
\hline $\begin{array}{l}\Delta \text { CHQ size } \\
\text { (number of staff) }\end{array}$ & \multicolumn{2}{|c|}{$\begin{array}{c}\text { Past change } \\
\text { (previous } 5 \text { years) }\end{array}$} & \multicolumn{2}{|c|}{$\begin{array}{l}\text { Anticipated change } \\
\text { (next } 5 \text { years) }\end{array}$} \\
\hline \multicolumn{5}{|c|}{ Magnitude of change } \\
\hline $0 \quad$ No change & 35 & $(33.65 \%)$ & 51 & $(43.97 \%)$ \\
\hline $1 \quad$ Change & 69 & $(66.35 \%)$ & 65 & $(56.03 \%)$ \\
\hline Total & 104 & $(100 \%)$ & 116 & $(100 \%)$ \\
\hline \multicolumn{5}{|c|}{ Directionality of change } \\
\hline$-1 \quad$ Decrease & 37 & $(35.58 \%)$ & 50 & $(43.10 \%)$ \\
\hline $0 \quad$ No change & 35 & $(33.65 \%)$ & 51 & $(43.97 \%)$ \\
\hline 1 Increase & 32 & $(30.77 \%)$ & 15 & $(12.93 \%)$ \\
\hline Total & 104 & $(100 \%)$ & 116 & $(100 \%)$ \\
\hline
\end{tabular}

\subsection{Corporate-level strategic change as antecedents of change in CHQ size}

Table 2 provides descriptive statistics for all of the variables in this study that are related to the anticipated structural change at the CHQ, as well as their correlations. The correlations between firm size and the anticipated decrease in CHQ size (0.64) and between CHQ size and the anticipated increase in CHQ size $(-0.44)$ are comparably high. With the exception of these two cases, all of the correlations between the independent and dependent variables are lower than 0.30 , which suggests that multicollinearity is not a problem in the analyses.

The baseline hypothesis refers to overall changes in the business portfolio - corporatelevel strategic change (CSC) - as an antecedent of change in CHQ size. Table 3 shows the binomial logistic regression models for the likelihood of change in CHQ size compared to the likelihood of no change. Model 1a, which includes the controls, indicates that prior changes in CHQ size and in the CHQ's cost effectiveness are positively related to the likelihood of change in CHQ size $(\mathrm{p}<0.05)$, and that industry and country effects play a role. Model $1 \mathrm{~b}$ includes the main effect and shows that CSC is positively related to the likelihood of change in CHQ size $(\mathrm{p}<0.05)$. Both models are significant $(\mathrm{p}<0.01)$. Model $1 \mathrm{~b}$ is superior to Model 1a, as both the statistical significance (Chisquared) and the practical significance (pseudo R-squared) are higher. Therefore, there is empirical support for $\mathrm{H} 1$.

In an extension of the baseline argument, $\mathrm{H} 2 \mathrm{a}$ and $\mathrm{H} 2 \mathrm{~b}$ hypothesize positive relationships between unrelated and related CSC, and changes in CHQ size. These hypotheses aim to explore whether differences exist between these two types of CSC. As these models are fairly similar to the previous models, I only point out the most noteworthy results (see Table 3). Model 2a contains only the controls. Model 2b shows that unrelated CSC is not significantly related to changes in CHQ size, while related CSC is positively related to the likelihood of such changes $(\mathrm{p}<0.01)$. 
S. Kunisch. Does headquarter structure follow corporate strategy? ...

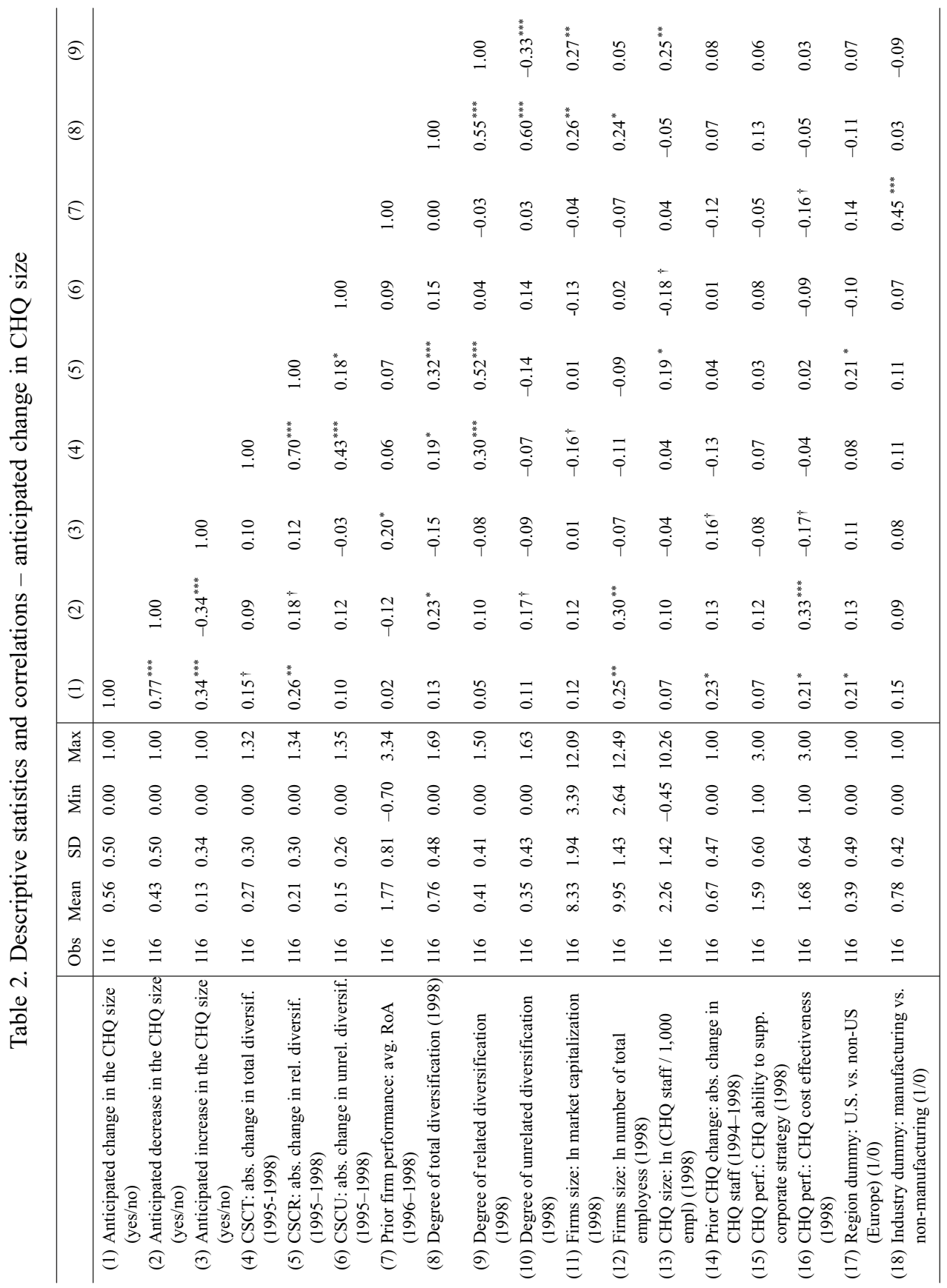




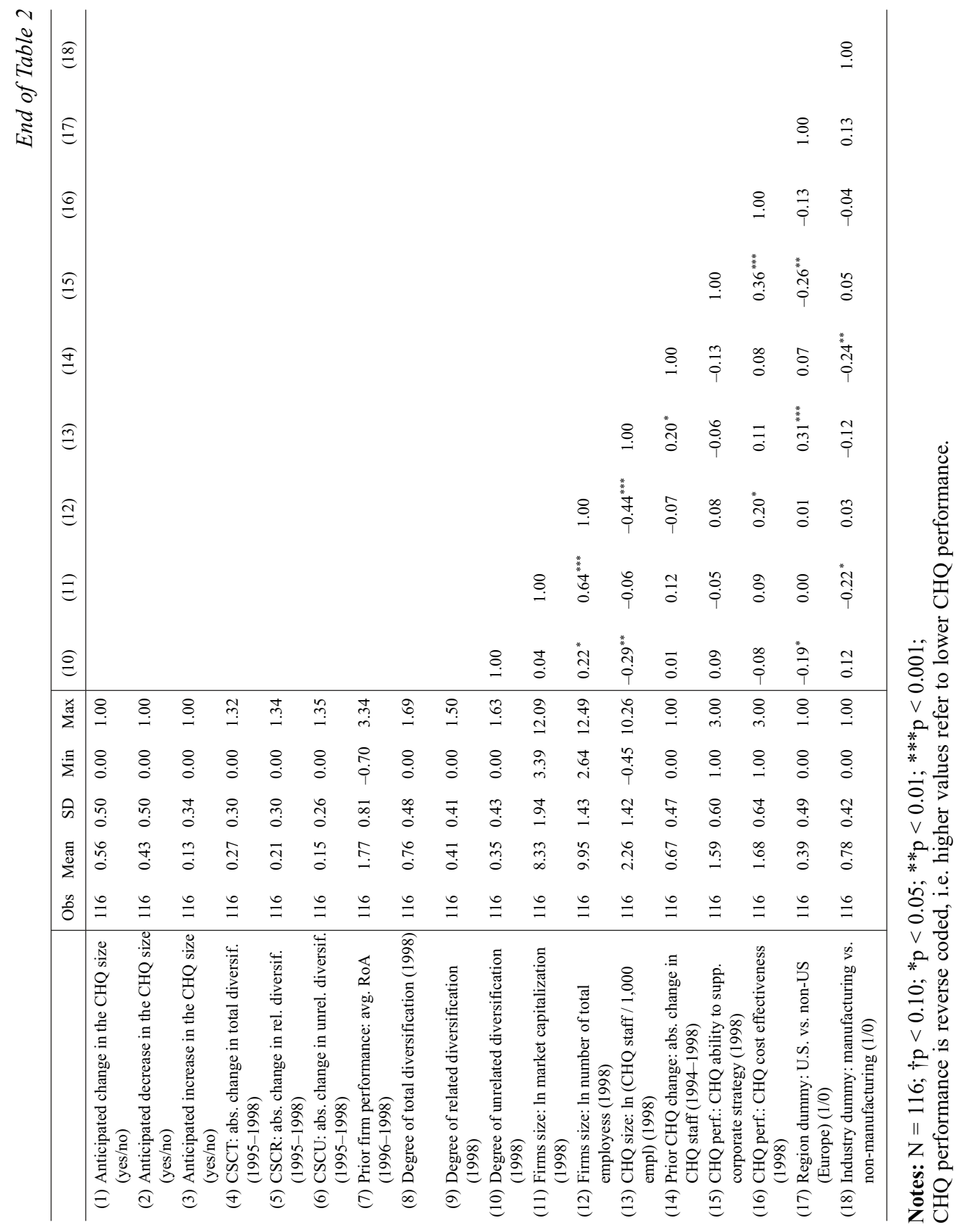


Table 3. Logistic regression models for the anticipated change in CHQ size

\begin{tabular}{|c|c|c|c|c|}
\hline \multirow{2}{*}{ Constant } & $-4.873 * * *$ & $-6.029 * * *$ & $-4.904 * * *$ & $-6.097 * * *$ \\
\hline & $(1.653)$ & $(1.809)$ & $(1.644)$ & $(1.883)$ \\
\hline \multicolumn{5}{|l|}{ Controlsa) } \\
\hline \multicolumn{5}{|l|}{ CHQ characteristics } \\
\hline \multirow{2}{*}{$\begin{array}{l}\text { Relative CHQ size: } \ln (\mathrm{CHQ} \text { staff/1,000 } \\
\text { total employees) (1998) }\end{array}$} & -0.062 & -0.109 & -0.005 & 0.007 \\
\hline & $(0.163)$ & $(0.167)$ & $(0.175)$ & $(0.187)$ \\
\hline \multirow{2}{*}{$\begin{array}{l}\text { Prior CHQ change: abs. change in CHQ } \\
\text { size (1994-1998) }\end{array}$} & $1.223^{* *}$ & $1.449 * * *$ & $1.216^{* *}$ & $1.303^{* *}$ \\
\hline & $(0.478)$ & $(0.511)$ & $(0.479)$ & $(0.514)$ \\
\hline \multirow{2}{*}{$\begin{array}{l}\text { CHQ performance: CHQ ability to } \\
\text { support corporate strategy }(1998)^{\text {b) }}\end{array}$} & 0.272 & 0.225 & 0.287 & 0.282 \\
\hline & $(0.401)$ & $(0.407)$ & $(0.400)$ & $(0.422)$ \\
\hline \multirow{2}{*}{$\begin{array}{l}\text { CHQ performance: CHQ cost } \\
\text { effectiveness }(1998)^{\text {a) }}\end{array}$} & $0.787^{* *}$ & $0.854^{* *}$ & $0.797 * *$ & $0.929 * *$ \\
\hline & $(0.386)$ & $(0.393)$ & $(0.389)$ & $(0.411)$ \\
\hline \multicolumn{5}{|l|}{ Firm characteristics } \\
\hline \multirow{2}{*}{$\begin{array}{l}\text { Prior firm performance: average RoA } \\
(1996-1998)\end{array}$} & -0.054 & 0.010 & -0.105 & -0.140 \\
\hline & $(0.313)$ & $(0.316)$ & $(0.319)$ & $(0.331)$ \\
\hline \multirow{2}{*}{ Degree of total diversification (1998) } & 0.520 & 0.264 & & \\
\hline & $(0.475)$ & $(0.493)$ & & \\
\hline \multirow{2}{*}{ Degree of related diversification (1998) } & & & 0.142 & -1.053 \\
\hline & & & $(0.632)$ & $(0.790)$ \\
\hline \multirow{2}{*}{$\begin{array}{l}\text { Degree of unrelated diversification } \\
\text { (1998) }\end{array}$} & & & 0.812 & 0.551 \\
\hline & & & $(0.580)$ & $(0.611)$ \\
\hline \multirow{2}{*}{$\begin{array}{l}\text { Firms size: ln market capitalization } \\
\text { (1998) }\end{array}$} & 0.119 & 0.180 & 0.140 & $0.240^{*}$ \\
\hline & $(0.123)$ & $(0.129)$ & $(0.127)$ & $(0.138)$ \\
\hline
\end{tabular}

Environmental characteristics: Industry dummies and country dummies ${ }^{\mathrm{c})}$

\section{Predictors}

CSCT: abs. change in total diversification (1995-1998)

CSCR: abs. change in related diversification (1995-1998)

CSCU: abs. change in unrelated diversification (1995-1998)

Log likelihood

Likelihood ratio Chi-squared

\begin{tabular}{c}
$1.870^{* *}$ \\
\hline$(0.896)$
\end{tabular}


End of Table 3

\begin{tabular}{lcccc}
\hline $\begin{array}{c}\Delta \text { CHQ size: Anticipated change } \\
\text { (next 5 years) }\end{array}$ & Model 1a & Model 1b & Model 2a & Model 2b \\
\hline Prob > Chi-squared & 0.0059 & 0.0019 & 0.0075 & 0.0004 \\
\hline Prob > $\Delta$ Chi-squared & & 0.0369 & & 0.0106 \\
\hline Pseudo R-squared & 0.1650 & 0.1959 & 0.1702 & 0.2427 \\
\hline$\Delta$ Pseudo R-squared & & 0.0309 & & 0.0725 \\
\hline Observations & 116 & 116 & 116 & 116 \\
\hline
\end{tabular}

Notes: $* * * \mathrm{p}<0.01, * * \mathrm{p}<0.05, * \mathrm{p}<0.1$, standard errors in parentheses.

a) I ran several robustness checks with other controls. These analyses led to similar results;

b) CHQ performance is reverse coded, i.e. higher values refer to lower CHQ performance;

c) Industry and country dummies are not reported for parsimony's sake.

Abs: absolute;

CHQ: Corporate headquarters;

CSCT: Total strategic change;

CSCR: Related corporate-level strategic change;

CSCU: Unrelated corporate-level strategic change.

I used the predicted probabilities to calculate the changes at $95 \%$ confidence intervals while holding all other variables at their mean values. A one standard deviation increase in related CSC (about 0.2952), cantered on the mean, increases the probability of changes in CHQ size by 0.2148 , while holding all other variables at their mean values. This difference is significant $(95 \%$ confidence interval: $0.0616,0.3680)$. A one standard deviation increase in unrelated CSC (about 0.2614), cantered on the mean, increases the probability of changes in CHQ size by 0.0967 , while holding all other variables at their mean values. This difference is not significant ( $95 \%$ confidence interval: -0.2370 , $0.4304)$. The difference in the increases in the probability of changes in CHQ size (0.2148 versus 0.0967) indicates that the influence of related CSC is greater than the influence of unrelated CSC.

\subsection{Performance consequences of changes in CHQ size}

With respect to the potential performance consequences, I proposed that firms benefit from changes in CHQ size to the extent that CSC (H3), unrelated CSC (H4a) and related CSC (H4b) occur. The analyses do not yield empirical support for any of these contingency effects or for the direct effects of changes in CHQ size on firm performance (to conserve space, the results of these analyses are not presented). Although the results do not support $\mathrm{H} 4 \mathrm{a}$, they do provide some support for the opposite relationship. There is a negative moderation effect of a high level of related CSC and changes in CHQ size on firm performance $(\mathrm{p}<0.05)$. I offer possible interpretations of this finding in the discussion section. Nevertheless, altogether the results provide no empirical support for the hypothesized contingency relationships which is similar to the non-findings in comparable contingency studies (Hambrick, Cannella 2004; Menz, Scheef 2014). 


\section{Discussion}

In this study, I explored the relationships between CSC, changes in CHQ size and firm performance. The analyses reveal that various factors at the firm and CHQ levels appear to influence changes in CHQ size. Specifically, the empirical findings suggest that CSC - especially related CSC - is positively related to the likelihood of changes in CHQ size. While the results provide support for the contingency and organizationaladaptation views of the relationships between CSC and CHQ change, I did not find empirical support for the expected performance implications.

\subsection{Contributions and practical implications}

The study makes at least three contributions. First, the study adds to research about the CHQ (Menz et al. 2015). While a vast majority of previous research on the CHQ adopts a static treatment of time, this study adds to the emerging body of research on the dynamic nature of the CHQ (Kunisch et al. 2015). The study reveals internal factors that can impede or foster changes at the CHQ. Specifically, while previous corporatelevel studies (Pettigrew 1985; Goold, Campbell 1987), and organizational change and inertia theories (Hannan, Freeman 1977, 1984, 1989) have nurtured concepts of CHQ inertia, the results of this study yield little empirical support for this viewpoint with respect to changes in CHQ size. In fact, this study suggests that CSC and lower CHQ performance foster the need for structural change at CHQs and, thereby, challenges the notion of CHQ inertia.

Second, this study adds to CSC research (Kunisch et al. 2017; Mueller, Kunisch 2017) by exposing differences between related and unrelated CSC. The notion of relatedness, and the distinction between related and unrelated diversification have become crucial in "static" diversification research (see Palepu 1985). Although scholars often rely on the firm's diversification strategy to study CSC in large firms and public companies (Kunisch et al. 2017; Mueller, Kunisch 2017), these "dynamic" studies utilize the total diversification index to calculate CSC. By exposing the differences in related and unrelated CSC, this study highlights the need for a more fine-grained examination of CSC. In addition, the only finding concerning the performance implications - a high level of related CSC together with change in CHQ size - is negatively associated with firm performance - hints at the potential disruptive effects of simultaneous changes in both corporate strategy concerns.

Third, the study adds to the classic strategy/structure literature (Chandler 1962). While previous studies empirically tested the dynamic contingency relationship between strategy and structure at the firm level, as proposed by Chandler (Amburgey, Dacin 1994; Galan, Sanchez-Bueno 2009), this study focuses on the specific relationships between changes in the corporate portfolio and structural change at the CHQ. In line with other empirical studies (Amburgey, Dacin 1994; Galan, Sanchez-Bueno 2009), my empirical findings support Chandler's (1962) observation that structure follows strategy.

The findings of this study have several practical implications pertaining to CHQ redesigns. First, the study reveals potential triggers of CHQ change, such as CHQ perfor- 
mance and changes in the business portfolio. Certain changes in the business portfolio appear to affect CHQ size, probably because these changes require adjustments in the way the business portfolio is managed. Thus, while the focus is often only on changes in the business portfolio, changes in how the business portfolio is managed and in the CHQ's design are equally important.

Second, I find no empirical evidence that changes at the CHQ directly influence firm performance. Related research suggests that "simply reducing the size of the headquarters is no guarantee of improved performance" (Collis et al. 2007: 402), and that a strong CHQ is particularly important in times of uncertainty (Raynor, Bower 2001). This, together with my findings, suggests that managers should be careful when implementing CHQ changes, adopt a considered approach and keep the disruptive effects in mind.

\subsection{Limitations and future research}

This study has several limitations that provide opportunities for future research. First, the sample of the study is constraint by: (a) four countries in the US and Europe, (b) public firms, and (c) large, diversified firms. Future research may therefore test whether the study's findings apply to other countries, different ownership conditions, and smaller or single-business firms.

Second, this study focuses on structural changes at the CHQ. While analysing the structures of an organizational entity is a practical approach for identifying the underlying activities and capabilities that have previously been applied (Grant 2003), structural change may be merely superficial, such that the personnel, behaviours or cultures remain the same (Ferlie, Pettigrew 1996). Future studies may thus investigate the degree to which structural change at the CHQ is not merely relabelling or symbolic activity, but reflects genuine CHQ change.

Third, there a few limitations related to the CSC measure. While I focused on productmarket diversification to capture $\mathrm{CSC}$, future research could use geographical diversification (Geringer et al. 2000), and re-examine the relationship between CSC and structural change at the CHQ. In addition, as product-market and geographical diversification focus on firm output rather than the firm's capabilities or core competences (Markides, Williamson 1996), future studies could investigate other measures of CSC.

Fourth, I acknowledge that I cannot entirely rule out the possibility of reverse causality and alternative explanations. Even though my theoretical arguments suggest that changes in the firm's portfolio should affect the decision to alter the size of the CHQ, the direction of this relationship may be the opposite. To mitigate endogeneity concerns, I relied on multiple data sources and applied a lagged empirical design to test the hypothesized relationships. Nevertheless, I cannot completely exclude the possibility that the CHQ's design may affect decisions regarding CSC. Future research could address this limitation, and focus on developing a deeper understanding of the causal mechanisms and processes that affect decisions concerning changes in CHQ size. In addition, scholars should further explore the potential relationships between firm growth (organic growth as well as mergers \& acquisitions) and changes at CHQ. 
Finally, the focus on internal contingencies and internal fit constitutes a theoretical limitation. Prior research stresses the importance of the CHQ as "a 'middleman' or broker between the business units on the one hand, and the external stakeholders on the other" (Birkinshaw et al. 2006: 686). Future research may thus examine the impact of external contingencies on structural change at the CHQ.

\section{Conclusions}

While the roles, functions and the designs of the CHQ have long attracted scholarly inquiries, scholars have become increasingly interested in the dynamic nature of the CHQ. In this study, I explored the relationships between changes in portfolio strategy (corporate-level strategic change, CSC) and changes in the size of the CHQ. The empirical findings suggest that although CSC generally fosters changes at the $\mathrm{CHQ}$, there are differences between related and unrelated CSC. While the performance effects remain unclear, the findings advance our knowledge about potential triggers to changes at the CHQ. The study's findings also yield ample opportunities for future research. While this study build on a "rational adaption" approach to explain changes at the CHQ, fellow scholars may explore political, symbolic and other factors that may foster and impede changes at the CHQ and shed light on the underlying processual dynamics that influence the relationships revealed in this study.

\section{Acknowledgements}

I am grateful to Björn Ambos, Michael Boppel, David Collis, Steve Floyd, Florian Kunze, Markus Menz, Sebastian Raisch, Christine Scheef, Markus Schimmer, Günter Müller-Stewens, and those who provided feedback at annual meetings of the Academy of Management and the Strategic Management Society for valuable comments on earlier versions of this paper.

\section{References}

Aiken, L. S.; West, S. G. 1991. Multiple regression: testing and interpreting interactions. Newbury Park, CA: Sage Publishing.

Amburgey, T. L.; Dacin, T. 1994. As the left foot follows the right? The dynamics of strategic and structural change, Academy of Management Journal 37(6): 1427-1452.

https://doi.org/10.2307/256794

Ansoff, H. I. 1965. Corporate strategy. New York: McGraw Hill.

Baaij, M. G.; Mom, T. J. M.; Van den Bosch, F. A. J.; Volberda, H. W. 2015. Why do multinational corporations relocate core parts of their corporate headquarters abroad?, Long Range Planning 48(1): 46-58. https://doi.org/10.1016/j.lrp.2012.07.001

Baron, R. M.; Kenny, D. A. 1986. The moderator-mediator variable distinction in social psychological research: conceptual, strategic, and statistical considerations, Journal of Personality and Social Psychology 51(6): 1173-1182. https://doi.org/10.1037/0022-3514.51.6.1173

Battilana, J.; Casciaro, T. 2012. Change agents, networks, and institutions: a contingency theory of organizational change, Academy of Management Journal 55(2): 381-398.

https://doi.org/10.5465/amj.2009.0891 
Bigley, G. A.; Wiersema, M. F. 2002. New CEOs and corporate strategic refocusing: how experience as heir apparent influences the use of power, Administrative Science Quarterly 47(4): 707-727. https://doi.org/10.2307/3094914

Birkinshaw, J.; Braunerhjelm, P.; Holm, U.; Terjesen, S. 2006. Why do some multinational corporations relocate their headquarters overseas?, Strategic Management Journal 27(7): 681-700. https://doi.org/10.1002/smj.541

Blau, P. M. 1970. A formal theory of differentiation in organizations, American Sociological Review 35(2): 201-218. https://doi.org/10.2307/2093199

Boeker, W. 1997. Strategic change: the influence of managerial characteristics and organizational growth, Academy of Management Journal 40(1): 152-170. https://doi.org/10.2307/257024

Buehner, R. 2000. Governance costs, determinants, and size of corporate headquarters, Schmalenbach Business Review 52(2): 160-181.

Burns, T.; Stalker, G. M. 1961. The management of innovation. London: Tavistock.

Campbell, A.; Goold, M.; Alexander, M. 1995. Corporate strategy: the quest for parenting advantage, Harvard Business Review 73(2): 120-132.

Cardinal, L. B. 2001. Technological innovation in the pharmaceutical industry: the use of organizational control in managing research and development, Organization Science 12(1): 19-36. https://doi.org/10.1287/orsc.12.1.19.10119

Carpenter, M. A. 2000. The price of change: the role of CEO compensation in strategic variation and deviation from industry strategy norms, Journal of Management 26(6): 1179-1198.

https://doi.org/10.1016/s0149-2063(00)00078-7

Chandler, A. D. 1962. Strategy and structure: chapters in the history of the American industrial enterprise. Cambridge, MA: MIT Press.

Chandler, A. D. 1991. The functions of the HQ unit in the multibusiness firm, Strategic Management Journal 12: 31-50. https://doi.org/10.1002/smj.4250121004

Chandler, A. D. 1992. Corporate strategy, structure and control methods in the United States during the 20th century, Industrial \& Corporate Change 1(2): 263-284.

https://doi.org/10.1093/icc/1.2.263

Chiarini, A. 2016. Corporate social responsibility strategies using the TQM: Hoshin Kanri as an alternative system to the balanced scorecard, The TQM Journal 28(3): 360-376.

https://doi.org/10.1108/TQM-03-2014-0035

Chiarini, A.; Vagnoni, E. 2015. World-class manufacturing by Fiat. Comparison with Toyota production system from a strategic management, management accounting, operations management and performance measurement dimension, International Journal of Production Research 53(2): 590-606. https://doi.org/10.1080/00207543.2014.958596

Cibin, R.; Grant, R. M. 1996. Restructuring among the world's leading oil companies, 1980-92, British Journal of Management 7(4): 283-302.

https://doi.org/10.1111/j.1467-8551.1996.tb00120.x

Collis, D. J.; Montgomery, C. A. 1998. Creating corporate advantage, Harvard Business Review 76(3): 71-83.

Collis, D. J.; Young, D.; Goold, M. 2007. The size, structure, and performance of corporate headquarters, Strategic Management Journal 28(4): 383-405. https://doi.org/10.1002/smj.595

Collis, D. J.; Young, D.; Goold, M. 2012. The size and composition of corporate headquarters in multinational companies: empirical evidence, Journal of International Management 18(3): 260-275. https://doi.org/10.1016/j.intman.2012.06.002

DiMaggio, P. J.; Powell, W. W. 1983. The iron cage revisited: institutional isomorphism and collective rationality in organizational fields, American Sociological Review 48(2): 147-160.

https://doi.org/10.2307/2095101 
Donaldson, L. 1987. Strategy and structural adjustments to regain fit and performance in defence of contingency theory, Journal of Management Studies 24(1): 1-24.

https://doi.org/10.1111/j.1467-6486.1987.tb00444.x

Donaldson, L. 1995. American anti-management theories of organization: a critique of paradigm proliferation. Cambridge: Cambridge University Press.

Donaldson, L. 2001. The contingency theory of organizations. Thousand Oaks, CA: Sage Publishing.

Dundas, K. N. M.; Richardson, P. R. 1982. Implementing the unrelated product strategy, Strategic Management Journal 3: 287-301. https://doi.org/10.1002/smj.4250030402

Economist. 2008. Corporate restructuring - centres of attention: companies may still have too many heads at headquarters, The Economist 15(November): 68-68. [online], [cited 15 October 2015]. Available from Internet: http://www.economist.com/node/12607384

Economist. 2014. Fighting the flab: corporate headquarters have put on weight, and need to slim down again, The Economist 22(March): 62-62. [online], [cited 15 October 2015]. Available from Internet: http://www.economist.com/news/business/21599354-corporate-headquarters-have-putweight-and-need-slim-down-again-fighting-flab

Ferlie, E.; Pettigrew, A. 1996. The nature and transformation of corporate headquarters: a review of recent literature and a research agenda, Journal of Management Studies 33(4): 495-523. https://doi.org/10.1111/j.1467-6486.1996.tb00166.x

Foss, N. J. 1997. On the rationales of corporate headquarters, Industrial \& Corporate Change 6(2): 313-338. https://doi.org/10.1093/icc/6.2.313

Galan, J. I.; Sanchez-Bueno, M. J. 2009. The continuing validity of the strategy-structure nexus: new findings, 1993-2003, Strategic Management Journal 30(11): 1234-1243.

https://doi.org/10.1002/smj.782

Geringer, J. M.; Tallman, S.; Olsen, D. M. 2000. Product and international diversification among Japanese multinational firms, Strategic Management Journal 21(1): 51-80.

https://doi.org/ 10.1002/(sici)1097-0266(200001)21:1<51::aid-smj77>3.0.co;2-k

Ginsberg, A. 1988. Measuring and modelling changes in strategy: theoretical foundations and empirical directions, Strategic Management Journal 9(6): 559-575.

https://doi.org/ 10.1002/smj.4250090604

Goodstein, J.; Boeker, W. 1991. Turbulence at the top: a new perspective on governance structure changes and strategic change, Academy of Management Journal 34(2): 306-330.

https://doi.org/10.2307/256444

Goold, M.; Campbell, A. 1987. Strategies and styles: the role of the centre in managing diversified corporations. Oxford, UK: Blackwell Publishing.

Goold, M.; Pettifer, D.; Young, D. 2001. Redesigning the corporate centre, European Management Journal 19(1): 83-91. https://doi.org/10.1016/S0263-2373(00)00073-6

Goold, M.; Young, D. 2005. When lean isn't mean, Harvard Business Review 83(4): 16-18.

Grant, R. M. 2003. Strategic planning in a turbulent environment: evidence from the oil majors, Strategic Management Journal 24(6): 491-517. https://doi.org/ 10.1002/smj.314

Hambrick, D. C.; Cannella, A. A. 2004. CEOs who have COOs: contingency analysis of an unexplored structural form, Strategic Management Journal 25(10): 959-979.

https://doi.org/10.1002/smj.407

Hambrick, D. C.; Mason, P. A. 1984. Upper echelons: the organization as a reflection of its top managers, Academy of Management Review 9(2): 193-206. https://doi.org/10.2307/258434

Hannan, M. T.; Freeman, J. 1977. The population ecology of organizations, American Journal of Sociology 82(5): 929-964. https://doi.org/10.1086/226424 
Hannan, M. T.; Freeman, J. 1984. Structural inertia and organizational change, American Sociological Review 49(2): 149-164. https://doi.org/10.2307/2095567

Hannan, M. T.; Freeman, J. 1989. Organizational ecology. Cambridge, MA: Harvard University Press.

Haveman, H. A. 1993. Organizational size and change: diversification in the savings and loan industry after deregulation, Administrative Science Quarterly 38(1): 20-50.

https://doi.org/10.2307/2393253

Hill, C. W. L.; Hitt, M. A.; Hoskisson, R. E. 1992. Cooperative versus competitive structures in related and unrelated diversified firms, Organization Science 3(4): 501-521.

https://doi.org/10.1287/orsc.3.4.501

Hill, C. W. L.; Hoskisson, R. E. 1987. Strategy and structure in the multiproduct firm, Academy of Management Review 12(2): 331-341. https://doi.org/10.2307/258539

Hoetker, G. 2007. The use of logit and probit models in strategic management research: critical issues, Strategic Management Journal 28(4): 331-343. https://doi.org/10.1002/smj.582

Hoskisson, R. E.; Hitt, M. A. 1988. Strategic control systems and relative R\&D investment in large multiproduct firms, Strategic Management Journal 9(6): 605-621.

https://doi.org/10.1002/smj.4250090607

Jacquemin, A. P.; Berry, C. H. 1979. Entropy measure of diversification and corporate growth, Journal of Industrial Economics 27(4): 359-369. https://doi.org/10.2307/2097958

Jensen, M. C.; Meckling, W. H. 1976. Theory of the firm: managerial behavior, agency costs and ownership structure, Journal of Financial Economics 3(4): 305-360.

https://doi.org/10.1016/0304-405x(76)90026-x

Jones, G. R.; Hill, C. W. L. 1988. Transaction cost analysis of strategy-structure choice, Strategic Management Journal 9(2): 159-172. https://doi.org/ 10.1002/smj.4250090206

Kelly, D.; Amburgey, T. L. 1991. Organizational inertia and momentum: a dynamic model of strategic change, Academy of Management Journal 34(3): 591-612.

https://doi.org/10.2307/256407

Kimberly, J. R.; Quinn, R. E. Q. 1984. Managing organizational transitions. Homewood IL: Richard D. Irwin.

Kleinbaum, A. M.; Stuart, T. E. 2014. Inside the black box of the corporate staff: social networks and the implementation of corporate strategy, Strategic Management Journal 35(1): 24-47. https://doi.org/10.1002/smj.2090

Kontes, P. 2004. A new look for the corporate center: reorganizing to maximize value, Journal of Business Strategy 25(4): 18-24. https://doi.org/10.1108/02756660410547359

Kunisch, S.; Bartunek, J.; Müller, J.; Huy, Q. 2017. Time in strategic change research, Academy of Management Annals 11(2): 1-60. https://doi.org/10.5465/annals.2015.0133

Kunisch, S.; Menz, M.; Ambos, B. 2015. Changes at corporate headquarters: review, integration and future research, International Journal of Management Reviews 17(3): 356-381.

https://doi.org/10.1111/ijmr.12044

Kunisch, S.; Müller-Stewens, G.; Campbell, A. 2014. Why corporate functions stumble, Harvard Business Review 92(10): 110-117.

Kunisch, S.; Müller-Stewens, G.; Collis, D. J. 2012. Housekeeping at corporate headquarters: international trends in optimizing the size and scope of corporate headquarters [online], [cited 15 October 2015]. Available from Internet: https://www.alexandria.unisg.ch/212825/1/CHQ_Survey_Report_2012_final.pdf

Laamanen, T.; Simula, T.; Torstila, S. 2012. Cross-border relocations of headquarters in Europe, Journal of International Business Studies 43(2): 187-210. https://doi.org/10.1057/jibs.2011.52 
Lawrence, P. R.; Lorsch, J. W. 1967. Organization and environment: managing differentiation and integration. Cambridge, MA: Harvard University Press.

Lorsch, J. W.; Allen III, S. A. 1973. Managing diversity and interdependence: an organizational study of multidivisional firms. Cambridge, MA: Harvard University Press.

Marcel, J. J. 2009. Why top management team characteristics matter when employing a chief operating officer: a strategic contingency perspective, Strategic Management Journal 30(6): 647-658. https://doi.org/10.1002/smj.763

Markides, C. C.; Williamson, P. J. 1996. Corporate diversification and organizational structure: a resource-based view, Academy of Management Journal 39(2): 340-367.

https://doi.org/10.2307/256783

Menard, S. 1995. Applied logistic regression analysis. Sage University Paper Series on Quantitative Applications in the Social Sciences. https://doi.org/10.4135/9781412983433

Menz, M.; Kunisch, S.; Collis, D. J. 2015. The corporate headquarters in the contemporary corporation: advancing a multimarket firm perspective, The Academy of Management Annals 9(1): 633-714. https://doi.org/10.1080/19416520.2015.1027050

Menz, M.; Scheef, C. 2014. Chief strategy officers: contingency analysis of their presence in top management teams, Strategic Management Journal 35(3): 461-471.

https://doi.org/10.1002/smj.2104

Miles, R. E.; Snow, C. C. 1978. Organizational strategy, structure and process. New York: McGraw-Hill.

Mintzberg, H. 1978. Patterns in strategy formation, Management Science 24(9): 934-948.

https://doi.org/10.1287/mnsc.24.9.934

Mintzberg, H.; Westley, F. 1992. Cycles of organizational change, Strategic Management Journal 13(Winter): 39-59. https://doi.org/10.1002/smj.4250130905

Mueller, J.; Kunisch, S. 2017. Central perspectives and debates in strategic change research, International Journal of Management Reviews (in press). https://doi.org/10.1111/ijmr.12141

Palepu, K. 1985. Diversification strategy, profit performance, and the entropy measure of diversification, Strategic Management Journal 6(3): 239-255. https://doi.org/10.1002/smj.4250060305 Pettigrew, A. M. 1985. The awakening giant: continuity and change in imperial chemical industries. Oxford: Blackwell Publishing.

Porter, M. E. 1987. From competitive advantage to corporate strategy, Harvard Business Review 65(3): 43-59.

Raynor, M. E.; Bower, J. L. 2001. Lead from the center: how to manage divisions dynamically, Harvard Business Review 79(5): 92-100.

Rumelt, R. P. 1974. Strategy, structure, and economic performance. Cambridge, MA: Harvard University Press.

Rumelt, R. P. 1982. Diversification strategy and profitability, Strategic Management Journal 3(4): 359-369. https://doi.org/10.1002/smj.4250030407

Sanders, G. W.; Carpenter, M. A. 1998. Internationalization and firm governance: the roles of CEO compensation, top team composition, and board structure, Academy of Management Journal 41(2): 158-178. https://doi.org/10.2307/257100

Stalk Jr., G. 2005. Rotate the core, Harvard Business Review 83(3): 18-19.

Wiersema, M. F.; Bantel, K. A. 1992. Top management team demography and corporate strategic change, Academy of Management Journal 35(1): 91-121. https://doi.org/10.2307/256474

Wiersema, M. F.; Bowen, H. P. 2009. The use of limited dependent variable techniques in strategy research: issues and methods, Strategic Management Journal 30(6): 679-692.

https://doi.org/10.1002/smj.758 
Williamson, O. E. 1975. Markets and hierarchies: analysis and antitrust implications. New York, NY: Free Press.

Young, D.; Goold, M.; Blanc, G.; Buehner, R.; Collis, D. J.; Eppink, J.; Tadao, K.; Seminario, G. J. 2000. Corporate headquarters: an international analysis of their roles and staffing. London, UK: Pearson Education.

Young, D. J. 1993. Headquarters staff - products of history or sources of distinctive skills?, Long Range Planning 26(5): 139-141. https://doi.org/10.1016/0024-6301(93)90086-u

Zhang, Y. 2006. The presence of a separate COO/president and its impact on strategic change and CEO dismissal, Strategic Management Journal 27(3): 283-300. https://doi.org/10.1002/smj.517

Sven KUNISCH, PhD, is a researcher and senior lecturer at the University of St. Gallen (Switzerland) where he also serves as the executive director of the Master's program in Business Management. He also holds or has held visiting positions at Harvard Business School (Harvard University), Saïd Business School (Oxford University) and WU Vienna. His research interests focus on corporate strategy, corporate headquarters, strategic change and executive successions. His works have been published in respective journals such as the Academy of Management Annals, International Journal of Management Reviews, Long Range Planning, Harvard Business Review, and MIT Sloan Management Review. He has also co-edited several management books on topics such as Mergers \& Acquisitions, Strategic Leadership and Demographic Change. 